\title{
PERKAWINAN CAMPURAN DI INDONESIA DITINJAU BERDASARKAN SEJARAH HUKUM, PERIODE 1848-1990
}

\author{
Tiurma Magihut Pitta Allagan ${ }^{1}$
}

\begin{abstract}
Abstrak
Mixed marriage has been long time done in Indonesia is included international mixed, inter regional mixed, inter local mixed, inter group and inter religious mixed marriage. Registration through international mixed marriage could be done, but to inter religious one is questioning. This article examines the history and maturity of mixed marriages, especially international marriages and mixed marriages between religions, as well as implementation and expansion. In the advance of mixed marriages in Indonesia has undergone a change. Mixed marriages are based GHR (prior Dutch Mixed Marriage Law in Indonesia) broader scope than mixed marriages according to Law No.1 of 1974. Mixed marriages in the GHR not only includes a mixed marriage between citizens, but also a mixed marriage between regions (inter-regional), inter-mixed marriage where the (interlocal), inter-marriage mixed marriage mixed groups and inter-religious. Mixed marriage in the Act No.1 of 1974 only covers a mixed marriage between citizens of the state.
\end{abstract}

Kata Kunci: hukum antar golongan, sejarah, perkawinan campuran

\section{Pendahuluan}

Setelah berlakunya Undang-undang No.1 tahun 1974 tentang Perkawinan, istilah "Perkawinan Campuran" menjadi suatu pembahasan di kalangan praktek maupun teori. Mengenai pelaksanaan perkawinan campuran juga telah banyak pembahasan, dimana salah satunya pembahasannya adalah mengenai pencatatan perkawinan campuran tersebut. Pada tulisan ini akan dibahas sedikit sejarah dan perkembangan perkawinan campuran di Indonesia.

${ }^{1}$ Penulis adalah Staf Pengajar Fakultas Hukum Universitas Indonesia. Alamat korespondensi: tiurma@ui.ac.id. 


\section{Definisi Perkawinan Campuran}

Di antara istilah-istilah hukum yang diterjemahkan dari bahasa Belanda pada tahun 1950-an, istilah "perkawinan campuran" sebagai terjemahan dari istilah hukum kolonial yaitu gemengde huwelijken telah diterima oleh banyak kalangan. ${ }^{2}$ Istilah Belanda tersebut adalah suatu istilah yang dipakai oleh undang-undang kolonial terkenal dengan nama Regeling op de Gemengde Huwelijken yang diatur dalam Staatblad (selanjutnya disebut Stb.) No.1898:158 atau GHR ${ }^{3}$.

Perkawinan campuran berdasarkan pasal 2 GHR diartikan sebagai "Perkawinan dari orang-orang yang di Indonesia tunduk kepada hukum yang berbeda." Menurut Sudargo Gautama, "hukum yang berbeda" ini dapat disebabkan karena: "...perbedaan kewarganegaraan, kependudukan dalam berbagai "regio" Kerajaan Belanda, golongan rakyat, tempat kediaman atau agama. ...". ${ }^{4}$ Dengan demikian, dapat disimpulkan bahwa secara umum berdasarkan "faktor penyebab" perkawinan campuran, perkawinan campuran dibagi menjadi: ${ }^{5}$

1. Perkawinan campuran internasional;

2. Perkawinan campuran antar-regio (antar-regionaal);

3. Perkawinan campuran antar-tempat (inter-locaal),

4. Perkawinan campuran antar-golongan; dan

5. Perkawinan campuran antar-agama.

1. Perkawinan campuran internasional

Perkawinan campuran internasional adalah perkawinan yang dilaksanakan oleh 2 (dua) orang mempelai yang berkewarganegaraan berbeda.

2. Perkawinan campuran antar-regio (antar-regionaal).

${ }^{2}$ Moh. Koesnoe, Istilah Perkawinan Campuran Sebagai Suatu Pengertian Hukum di Indonesia,. Varia Peradilan, No.159 Agustus 1990, hal. 130.

${ }^{3}$ Penetapan Raja atau Beslit Kerajaan 29 Desember 1896 No.23, Staatblad No.1898:158 (Regeling op de Gemengde Huwelijken), atau Peraturan Perkawinan Campuran, lebih sering disingkat sebagai "GHR".

4 Sudargo Gautama, "Segi-segi Hukum Peraturan Perkawinan Campuran", (Bandung: Citra Aditya Bakti, 1996), hal. 3.

${ }^{5}$ Ibid. 
Perkawinan campuran antar-regio ini selamanya adalah perkawinan campuran. Perkawinan ini adalah perkawinan yang dilakukan oleh 2 (dua) orang mempelai, dimana salah satu mempelai berasal dari tempat yang menjadi koloni dari mempelai yang lain. ${ }^{6}$ Perkawinan campuran antar-regio ini dapat diberikan contoh sebagai berikut ini: ${ }^{7}$

......perkawinan antara orang Indonesia yang bertempat tinggal dan menetap di negeri belanda yang hendak menikah, secara diwakilkan dengan orang Indonesia yang bertempat tinggal dan menetap di Indonesia ${ }^{8}$, antara orang Belanda yang secara sambil lalu berada di Indonesia dan menikah dengan orang Belanda yang bertempat tinggal dan menetap di Indonesia. ..."

Berkaitan dengan sejarah perjuangan kemerdekaan bangsa Indonesia, sejak tanggal 27 Desember 1949 - Konferensi Meja Bundar, perkawinan campuran antar-regio (antar regionaal) tersebut merupakan sejarah. ${ }^{9}$

3. Perkawinan campuran antar-tempat.

Perkawinan campuran antar-tempat dapat diartikan sebagai berikut:

“...... perkawinan antara orang-orang Indonesia sendiri yang berasal dari satu suku bangsa atau daerah yang berlainan dan hidup dalam berbagai lingkungan hukum (rechtssferen, rechtskringen). Misalnya perkawinan antara orang Batak dengan perempuan Sunda, seorang Jawa dengan wanita Lampung dan sebagainya..... "10

Perkawinan semacam ini merupakan suatu perkawinan campuran yang tertua dari segala rupa perkawinan campuran di Indonesia.

4. Perkawinan campuran antar-agama.

${ }^{6}$ Ibid.

${ }^{7}$ Ibid., hal. 158.

${ }^{8}$ Contoh dari Kollewijn. Secara teori, contoh ini dapat diterima, namun berdasarkan peraturan perkawinan di Indonesia saat ini, perkawinan yang dilakukan dengan perwakilan tidak dapat dilakukan di Indonesia.

${ }^{9}$ Sudargo Gautama, Op. Cit., hal.157.

${ }^{10}$ Ibid., hal.4. 
Perkawinan antar-agama dapat diartikan sebagai suatu perkawinan yang dilakukan oleh kedua mempelai yang berbeda agama.

Menurut pendapat Moh. Koesnoe, dalam hal ini yang penting bukanlah agamanya namun stelsel hukum yang berlaku bagi para mempelai. ${ }^{11}$

5. Perkawinan campuran antar-golongan.

Perkawinan campuran antar-golongan, adalah perkawinan yang dilakukan oleh 2 (dua) mempelai yang tunduk pada hukum berbeda. $\mathrm{Hal}$ ini dipahami dengan mengingat sejarah di bangsa Indonesia. Pada jaman kolonial orang-orang yang bertempat tinggal di Hindia Belanda (sekarang Negara Kesatuan Republik Indonesia) dibagi dalam golongan-golongan rakyat, yaitu golongan Bumiputera, golongan Timur Asing dan golongan Eropa. Dilihat dari sejarah, penggolongan penduduk ini berubah dari waktu ke waktu. ${ }^{12}$

${ }^{11}$ Ibid., Pendapat Prof Koesno dapat dikutip dari Soedargo Gautama, Op. Cit., hal. 157, sebagai berikut: “.... Di dalam hal dua orang berlainan agama mengadakan suatu perkawinan yang dilihat oleh tata hukum kita pada masa lalu bukanlah segi agamanya. Akan tetapi yang penting di ingat ialah bahwa menurut sistem tata hukum kita di masa silam, orang yang berlainan agama, khususnya bagi orang yang beragama Islam bila kawin dengan orang yang beragama Kristen maka yang berbeda ialah hukum menguasai hidup mereka masingmasing yang dalam perkawinan akan menjadi soal. ...".

${ }^{12}$ Natasya Yunita Sugiastuti, "Tradisi Hukum Cina: Negara dan Masyarakat (Studi mengenai peristiwa-peristiwa Hukum di Pulau Jawa Zaman Kolonial 1870-1942)", (Jakarta: Program Pasca Sarjana Fakultas Hukum Universitas Indonesia, 2003), hal.186-214.

Pembagian golongan penduduk ini dapat dibagi dalam 3 masa: (a) Masa Algemene Bepalingen van Wetgeving voor Indonesie (1848-1854). Penggolongan penduduk diatur berdasarkan Pasal 6-10 Algemene Bepalingen van Wetgeving voor Indonesie (selanjutnya disebut "AB"), yakni penduduk yang ada di Hindia Belanda dibagi dalam dua golongan pokok, yakni golongan Eropa dan golongan Bumiputera. Mereka yang bukan orang Eropa atau Bumiputera dipersamakan dengan orang Eropa atau dengan Bumiputera dengan memakai ukuran agama yang dianut. Jadi pembagian golongan menurut pasal-pasal itu hanya berdasarkan kepada perbedaan agama, yaitu yang beragama Kristen selain Eropa disamakan dengan orang Eropa dan semua orang yang tidak beragama Kristen disamakan dengan orang Bumiputera. Bagi golongan Eropa dan Timur Asing tunduk pada hukum perdata Belanda, sedangkan golongan Bumiputera tunduk pada Hukum Adat. (b) Masa Regerings Reglement (1854-1926). Dengan terbentuknya Regerings Reglement ditahun 1854 (selanjutnya disebut sebagai "RR"), penggolongan penduduk berdasarkan Pasal 6-10 AB digantikan oleh Pasal 109 RR. Pasal tersebut tetap membagi penduduk yang ada di Hindia Belanda dalam dua golongan pokok, yakni golongan Eropa dan golongan Bumiputera. Mereka yang bukan golongan Eropa atau Bumiputera disamakan dengan golongan dengan golongan Eropa atau dengan golongan Bumiputera tidak berdasarkan perbedaan agama. Orang Bumiputera beragama Kristen tetap masuk dalam golongan Bumiputera, demikian juga orang Cina, Arab dan India dipersamakan dengan golongan Bumiputera. Orang-orang Kristen yang bukan Cina, Arab atau India seperti Amerika, Afrika Selatan dan Australia, Persia Kristen, Afrika Kristen dan sebagainya 
Perkawinan diantara 2 (dua) orang mempelai yang merupakan anggota golongan penduduk yang tunduk pada sistem hukum yang berbeda (sebagai akibat perbedaan golongan penduduk) di Indonesia inilah yang disebut sebagai perkawinan campuran antar-golongan.

Dengan adanya pembagian seperti diuraikan di atas, maka suatu perkawinan campuran dapat diklasifikasikan dalam satu macam perkawinan campuran saja, misalnya perkawinan campuran antar-golongan dimana kedua mempelai satu agama tetapi dari golongan penduduk yang berbeda. Dalam peristiwa lain, perkawinan campuran dapat diklasifikasikan dalam dua atau bahkan beberapa perkawinan campuran, misalnya kedua mempelai berbega agama dan golongan penduduk.

\section{Perkawinan Campuran sebelum berlakunya GHR}

Sebelum diberlakukannya GHR pada tahun 1848, perkawinanperkawinan antara orang-orang Kristen dan orang-orang non-Kristen di Hindia Belanda (perkawinan campuran antar-agama) dilarang. Larangan tersebut kemudian ditiadakan, namun ditetapkan lebih lanjut Pasal 15 Bepalingen omtrent de invoering en den overgang tot de nieuwe wetgeing atau Ketentuan-ketentuan tentang diberlakukan dan peralihan pada perundang-undangan baru, Stb. 1848 No.10, atau dikenal dengan singkatan Ov. ${ }^{13}$

Pasal 15 Ov ini menyatakan bahwa seorang bukan Eropa yang hendak melangsungkan perkawinan dengan seorang Eropa, harus tunduk terlebih

dipersamakan dengan golongan Eropa. Pada tahun 1920, Pasal 75 dan Pasal 109 RR mengalami perubahan yang kemudian dikenal dengan sebutan RR (Baru) dan mulai berlaku mulai tanggal 1 Januari 1920 sampai dengan 1926. Berdasarkan RR (Baru), mereka yang bukan golongan Eropa dan bukan golongan Bumiputera dikelompokkan sebagai golongan Timur Asing. Dengan demikian ada 3 golongan penduduk, yaitu: (i) Golongan Eropa; (ii) Golongan Timur Asing; dan (iii) Golongan Bumiputera. Bagi golongan Eropa dan Timur Asing tunduk pada hukum perdata Belanda, sedangkan golongan Bumiputera tunduk pada Hukum Adat. (c) Masa Indische Staatsregeling (1926-1942). Pada tanggal 23 Juni 1925 berdasarkan Stb. 1925:415 dan 416, RR diubah dan diganti menjadi Indische Staatsregeling (selanjutnya disebut IS), dan mulai berlaku mulai tanggal 1 Januari 1926 berdasarkan Stb. 1925:577. Berdasarkan Pasal 131 IS jo. Pasal 161 dan 163 IS, secara garis besar penduduk Hindia Belanda dan pemberlakuan hukum yang berlaku bagi setiap golongan dibagi menjadi (i) Golongan Eropa, yang tunduk pada hukum Belanda; (ii) Golongan Timur Asing, yang tunduk pada hukum Belanda dan untuk hal-hal yang belum diatur bagi mereka berlaku peraturan yang bertalian dengan agama dan adat kebiasaan mereka; dan (iii) Golongan Bumiputera, yang tunduk pada hukum Adat.

${ }^{13}$ Wila Chandrawila Supriadi, Op. Cit., hal. 89. 
dahulu pada hukum perdata Eropa. Oleh karena itu terhadap perkawinan campuran ini selamanya selalu berlaku hukum perdata Eropa. ${ }^{14}$

\section{Perkawinan Campuran menurut GHR}

\section{A. Definisi Perkawinan Campuran berdasarkan GHR}

Seperti telah disebutkan di atas, berdasarkan pasal 1 GHR "Perkawinan Campuran" dinyatakan sebagai berikut: ${ }^{15}$

Yang dinamakan Perkawinan Campuran, ialah perkawinan antara orang-orang yang di Indonesia tumduk kepada hukum-hukum yang berlainan.

Di sini dapat dilihat bahwa perkawinan campuran yang diatur di sini bukan berdasarkan perbedaan nasionalitas, agama, kedudukan atau daerah domisili, melainkan oleh karena para pihak yang bersangkutan tunduk pada tatanan-tatanan hukum yang berbeda. ${ }^{16}$ Ruang lingkup perkawinan campuran ini dibatasi bahwa perkawinan tersebut dilakukan di Indonesia.

Jika dihubungkan dengan definisi secara umum di atas, definisi GHR ini mencakup kelima definisi perkawinan campuran yang telah dibahas pada butir I di atas.

Namun, menurut Sudargo Gautama, dikaitkan dengan Hukum Antar Tata Hukum (HATAH). ${ }^{17}$ perkawinan yang tercakup dalam pasal 1 GHR tersebut terdapat beberapa aliran, yaitu: ${ }^{18}$

${ }^{14}$ Sudargo Gautama, "Hukum Antargolongan Suatu Pengantar", Op. Cit., hal. 129.

${ }^{15}$ Terjemahan ini diambil dari K. Wantjik Saleh, "Hukum Perkawinan Indonesia", (Jakarta: Ghalia Indonesia, 1976), Lampiran 11, hal. 209-211.

${ }^{16}$ Wila Chandrawila Supriadi, "Hukum Perkawinan Indonesia \& Belanda, Suatu Penelitian Sejarah Hukum Perbandingan tentang Hukum Perkawinan Indonesia dan Belanda dalam Periode Tahun 1945 Sampai Sekarang", (Bandung: Mandar Maju, 2002), hal. 89.

${ }^{17}$ HATAH adalah Keseluruhan peraturan dan keputusan hukum yang menunjukkan stelsel-stelsel manakan yang berlaku atau apakah yang merupakan hukum, jika hubunganhubungan dan peristiwa-peristiwa antara warga (warga) negara dalam satu negara, memperlihatkan titik-titik pertalian dengan stelsel-stelsel dan kaidah-kaidah hukum yang berbeda dalam lingkungan kuasa waktu, tempat, pribadi dan soal-soal. HATAH sering pula disebut sebagai Hukum Perselisihan. Lihat Sudargo Gautama (Gouw Giok Siong), "Hukum Antargolongan Suatu Pengantar", Cet. Ke-11, (Jakarta: Ichtiar Baru Van Hoeve, 1993), hal.40. 
......telah menjadi tetap, antara para sarjana hukum yang berkecimpung dalam HATAH-Indonesia, bahwa yang terang termasuk dalam perumusan pasal 1 GHR itu adalah perkawinan Hukum Antar-Golongan. Mengenai perkawinan HAA (Interreligius recht, hukum antar-agama) dan HAT (interlocaal recht), hukum antar-tempat) terdapat perbedaan faham: ada yang menganggapnya termasuk, karena mereka menganut pendirian luar dari GHR. Tetapi ada pula yang merumuskannya secara "sempit" dan menganggap baik HAA maupun HAT tidak termasuk, sedangkan ada pula yang mengambil jalan tengah dengan menganggap HAA turut termasuk tetapi HAT tidak.

Jadi menurut Sudargo Gautama, terdapat beberapa aliran dalam menafsirkan pasal 1 GHR tersebut ${ }^{19}$ :

1. Aliran sempit, pendapat yang menyatakan bahwa perkawinan campuran hanyalah perkawinan campuran yang terjadi diantara 2 (dua) orang mempelai yang berbeda golongan penduduk (antargolongan);

2. Aliran tengah atau setengah luas setengah sempit, aliran yang menyatakan bahwa yang termasuk perkawinan campuran adalah perkawinan antar golongan dan perkawinan antar agama. Menurut penganut aliran ini, perkawinan-perkawinan antar tempat (yakni antara orang-orang dari suku bangsa berlainan, tetapi dalam golongan rakyat "bumiputera" yang sama, misalnya perempuan Sunda yang menikah dengan lelaki Palembang tidak termasuk dalam ruang lingkup GHR.

3. Aliran luas, aliran yang menyatakan bahwa yang termasuk perkawinan campuran adalah perkawinan antar golongan, perkawinan antar agama, dan perkawinan antar tempat.

4. Mengenai pertanyaan apakah GHR berlaku puka untuk perkawinan antar-agama dan antar-tempat ternyata tidak ada kata sepakat. Namun banyak para sarjana hukum dan juga Panitya

Lihat juga Sudargo Gautama, "Pengantar Hukum Perdata Internasional Indonesia", (Jakarta: Binacipta, 1987), hal.12.

${ }^{18}$ Sudargo Gautama, "Hukum Perdata Internasional Indonesia", Jilid III Bagian 1, (Bandung; Alumni, 1981), hal. 131-132.

${ }^{19}$ Lihat pula: Sudargo Gautama, "Hukum Antargolongan", Op. Cit., hal.130. 
Negara (Nederburgh) yang telah membuat GHR dalam penjelasannya menjunjung pendirian aliran luas di atas. ${ }^{20}$

$\mathrm{Hal}$ ini didukung pula bahwa berdasarkan pasal 7 GHR ayat 2 itu sendiri yang menyatakan bahwa perbedaan agama, bangsa atau asal itu sama sekali bukanlah menjadi halangan untuk perkawinan itu.

\section{B. Pelaksanaan Perkawinan Campuran}

Berdasarkan pasal 6 ayat 1 GHR dinyatakan bahwa:

...Perkawinan Campuran dilangsungkan menurut hukum yang berlaku untuk si suami, kecuali izin dari kedua belah pihak bakal mempelai, yang selalu harus ada. ...

Berdasarkan pasal tersebut di atas dinyatakan bahwa Perkawinan Campuran dilaksanakan berdasarkan hukum si suami. Mengingat golongan penduduk yang terjadi berdasarkan pasal 131 IS jo.161 IS dan 163 IS, terlihat bahwa dalam perkawinan campuran terdapat 2 (dua) kemungkinan. Bila si suami dari golongan Eropa atau Timur Asing maka perkawinan dilangsungkan dengan mengikuti prosedur yang ditentukan berdasarkan Hukum Belanda. Namun bila si (calon) suami dari golongan Bumiputera, maka perkawinan dilangsungkan berdasarkan Hukum Adat.

Pengecualian bagi pemberlakuan hukum tersebut hanyalah berlaku bagi "izin" yang berasal dari kedua belah pihak dari mempelai. Tanpa memandang asal golongan penduduk, "izin" dari kedua belah pihak mempelai harus ada. ${ }^{21}$

${ }^{20}$ Ibid., hal. 131.

${ }^{21}$ Pasal 6 GHR ayat 2 sampai dengan ayat 5, dinyatakan bahwa:

(2) Jika menurut hukum yang berlaku untuk si lelaki itu tidak ada seorang yang ditentukan untuk mengawasi atau diwajibkan melangsungkan pernikahan itu, maka pernikahan itu dilangsungkan oleh Kepala golongan si lelaki atau wakilnya dan jika Kepala itu tak ada, maka diawasi oleh Kepala Kampung atau Kepala Desa, di mana perkawinan itu dijalankan.

(3) Jika hukum itu (yang berlaku untuk si lelaki) tidak mengharuskan, bahwa perkawinan itu dibuktikan dengan surat nikah, maka orang yang mengadakan perkawinan campuran, atau di bawah pengawasan mana perkawinan ccampuran itu dilangsungkan, wajib membuat surat nikah menurut model yang ditetapkan oleh Gubernur Jenderal.

(4) Jika orang tersebut tidak dapat menulis, maka surat nikah harus ditulis seorang yang ditunjuk untuk itu oleh Kepala Pemerintah Daerah. 
Berdasarkan pasal 6 GHR, perkawinan campuran dapat dilaksanakan dengan mengikuti proses formil yang hukum si suami. Selanjutnya, perkawinan campuran tersebut wajib untuk dicatatkan di Catatan Sipil untuk bangsa Eropah dan bangsa yang disamakan dengan bangsa Eropah. Pencatatan tersebut berlaku baik perkawinan campuran yang dilaksanakan berdasarkan Hukum Adat karena si suami berasal dari golongan Bumiputera, maupun berdasarkan Hukum Eropah karena si suami berasal dari golongan Eropa atau Timur Asing.

Dalam pelaksanaan perkawinan campuran ini, calon mempelai perempuan harus telah memenuhi seluruh persyaratan yang ditentukan oleh hukum yang berlaku baginya. Keterangan tersebut haruslah tertulis dan dituangkan dalam suatu surat keterangan. Surat keterangan ini tidak berlaku lagi jika dalam jangka waktu 1 (satu) tahun perkawinan tersebut tidak dilaksanakan. Hal ini diatur dalam Pasal 7 GHR ayat 1,3 dan $5 .^{22}$

Jika untuk si perempuan berlaku hukum keluarga Eropa (EuropeeschFamilie-recht) sedang untuk si lelaki tidak, maka orang yang mengawinkan atau yang mengawasi perkawinan itu, harus mengirimkan surat nikah itu kepada Pegawai Pencatatan Sipil untuk bangsa Eropah dan bangsa yang disamakan dengan bangsa Eropah, di daerah di mana perkawinan itu dijalankan, dalam masa yang akan ditetapkan oleh ordonansi. Surat nikah itu oleh pegawai tersebut dicatat dalam suatu buku pendaftaran, yang disediakan khusus untuk keperluan itu, serta disimpan olehnya".

${ }^{22}$ Pasal 7 GHR ayat 1, 3 dan 5 berbunyi sebagai berikut:

(1) Perkawinan campuran tak dapat dilakukan, sebelum terbukti bahwa halhal yang mengenai diri si perempuan itu telah dipenuhi yakni aturanaturan atau syarat-syarat yang ditentukan oleh hukum yang berlaku untuk si perempuan itu, yang bersangkut paut dengan sifat-sifat dan syaratsyarat yang diperlukan untuk melangsungkan perkawinan dan juga formaliteit-formaliteit yang harus dijalankan sebelum perkawinan itu dilakukan.

(3) Unruk membuktikan, bahwa aturan-aturan atau syarat-syarat tersebut dalam ayat 1 dari pasal ini sudah dipenuhi dan oleh karena itu sudah ada rintangan lagi untuk melangsungkan perkawinan campuran, maka oleh mereka yang menurut hukum yang berlaku si perempuan diwajibkan mengadakan nikah atau yang kuasa mengakadkan nikah dari tempat kediaman si perempuan, diberikan surat keterangan dengan percuma serta tidak memakai meterai, kecuali jika perkawinan itu akan terjadi antara dua pihak yang takluk pada hukum keluarga eropah. Jika orang yang tersebut itu menurut hukum yang berlaku untuk si perempuan tidak ada, maka keterangan itu diberikan oleh Kepala Penduduk golongan si perempuan itu, atau jika Kepala demikian itu tak ada, oleh orang yang ditentukan oleh Kepala Pemerintahan Daerah di tempat kediaman si perempuan, atau di mana si perempuan bertempat tinggal. 
Surat Keterangan ini adalah wajib, oleh karenanya apabila surat keterangan tidak dapat diperoleh dari pihak-pihak yang disebutkan dalam Pasal 7 GHR, maka surat keterangan tersebut dapat diperoleh dari pengadilan. Hal ini diatur dalam Pasal 8 GHR ayat $1 .^{23}$

Berdasarkan Pasal $10 \mathrm{GHR}^{24}$, perkawinan campuran dapat pula dilangsungkan di luar wilayah Indonesia, asal saja mengikuti peraturan yang berlaku di wilayah tersebut dan tidak melanggar ketentuan hukum GHR ini. Hal ini diatur, yang secara lengkap berbunyi sebagai berikut:

\section{Ketentuan Huwelijk Ordonnantie Christen-Inlanders Java, Minahasa en Amboina, atau Ordonansi Perkawinan Indonesia - Kristen untuk Jawa, Minahasa dan Ambon tanggal 15 Desember 1933, Stb. 1933 No.74 (selanjutnya disebut sebagai HOCI)}

Asas persamarataan sebagaimana terkandung dalam Pasal 2 GHR, ternyata dapat disimpangi dengan aturan dalam Pasal $75^{25}$ dan Pasal 73 HOCI.

(5) Keterangan tersebut pada ayat 3 pasal ini menurut hukum tidak mempunyai kekuatan lagi jika perkawinan itu tidak dijalankan dalam masa setahun, sesudah keterangan itu diberikan."

${ }^{23}$ Pasal 8 GHR ayat 1 berbunyi sebagai berikut "Jika surat keterangan itu tidak diberikan, maka atas permintaan yang berkepentingan atau mereka yang berkepentingan, Pengadilan biasa dari si perempuan memberi keputusan dengan tidak beracara serta dengan tidak boleh dimintakan banding (appel) lagi tentang penolakan pemberian surat keterangan itu beralasan atau tidak."

24 Pasal 10 GHR berbunyi sebagai berikut: "Perkawinan campuran yang dilangsungkan di luar Indonesia atau di bagian Indonesia yang masih mempunyai pemerintahan sendiri (Indonesisch Zelfbestuur) adalah sah, jika perkawinan itu dilakukan menurut aturan-aturan yang berlaku di negeri tersebut, di mana perkawinan tiu dilangsungkan, asal saja kedua pihak tidak melanggar aturan-aturan atau syarat-syarat dari hukum yang berlaku untuk mereka masing-masing, ialah tentang sifat-sifat dan syarat-syarat yang diperlukan untuk melangsungkan pernikahan."

${ }^{25}$ Terjemahan ini diambil dari K. Wantjik Saleh, "Hukum Perkawinan Indonesia", (Jakarta: Ghalia Indonesia, 1976), Lampiran 12, hal. 212-228. Pasal 75 HOCI berbunyi sebagai berikut:

(1) Perkawinan seorang laki-laki tidak beragama Kristen dengan seorang perempuan beragama Kristen, atas permintaan mereka, dapat dikukuhkan dengan menurut segala ketentuan ordonansi ini dan Reglemen Catatan Sipil Indonesia - Kristen Jawa, Madura, Minahasa dan Ambon, Saparua dan Banda (Stb.1933 No.75). Dalam hal itu perkawinan suami istri itu seluruhnya tunduk pada Ordonansi ini. 
Pasal 75 HOCI ini memberi kesempatan kepada pihak laki-laki Bumiputera/Indonesia bukan Kristen untuk melakukan pilihan hukum diwaktu mengawini perempuan Bumiputera/Indonesia Kristen. Pihak laki-laki dapat memilih hukum yang berlaku bagi pihak perempuan (istri) sebagai hukum untuk hubungan perkawinannya. Dengan demikian dapatlah pihak laki-laki memilih HOCI sedangkan ia sendiri tidak beragama Kristen.

Pasal 73 HOCI ayat $1^{26}$ memberikan pilihan hukum yang jika dianalisa lebih lanjut dapat merupakan pengecualian dari Pasal 2 GHR. Dengan Pasal 73 HOCI ini terbuka kesempatan bagi kedua mempelai untuk mengajukan permohonan kepada Pengadilan Negeri agar untuk selanjutnya dalam perkawinan mereka diatur oleh HOCI, bilamana salah satu pihak dalam perkawinan beralih agama menjadi Kristen. Apabila yang beralih agama adalah pihak perempuan (istri), maka yang berlaku bagi perkawinan campuran tersebut adalah HOCI. Dalam hal ini terjadi pengecualian Pasal 2 GHR, karena yang berlaku bagi perkawinan campuran adalah hukum si perempuan (istri) walaupun pilihan ini dilakukan dengan bantuan si laki-laki (suami).

Pilihan hukum yang telah dilakukan berdasarkan $\mathrm{HOCI}$ ini, diatur lebih lanjut dalam Pasal $74 \mathrm{HOCI}$, yang menyatakan bahwa perkawinan yang dilangsungkan berdasarkan ordonansi ini atau yang kemudian hari ditundukkan pada ordonansi ini maka ordonansi ini berlaku terus terhadap perkawinan tersebut, walaupun salah seorang diantara mereka itu pindah agama lain, selain agama Kristen. Hal ini berarti bahwa sekali pilihan hukum terhadap HOCI dilakukan, maka pilihan tersebut tidak dapat ditarik kembali. Atau dalam HATAH sering kali dianasir sebagai prinsip "Sekali dibawah HOCI tetap dibawah HOCI" ${ }^{27}$

${ }^{26}$ Pasal 73 HOCI ayat 1 berbunyi sebagai berikut: "Suami-istri secara bersamasama dapat meminta Pengadilan negeri supaya ditentukan dengan putusan bahwa perkawinan mereka selanjutnya tunduk pada ordonansi ini, apabila salah seorang diantara suami-istri, sebelum atau sesudah ordonansi ini berlakumasuk agama Kristen sesudah kawin".

${ }^{27}$ Sudargo Gautama, “Hukum Antargolongan Suatu Pengantar”, Op. Cit., hal.147. 


\section{Perkawinan Campuran menurut UU No.1 tahun 1974}

\section{A. Definisi Perkawinan Campuran}

Perkawinan Campuran menurut UU No.1 tahun 1974, didefinisikan dalam Pasal 57 yang berbunyi sebagai berikut:

Yang dimaksud dengan perkawinan campuran dalam Undang-undang ini ialah perkawinan antara dua orang yang di Indonesia tunduk pada hukum yang berlainan, karena perbedaan kewarganegaraan dan salah satu pihak berkewarganegaraan Indonesia.

Dalam hal ini, definisi perkawinan campuran menjadi lebih sempit dibandingkan dengan GHR, karena pertautan hukum yang berbeda ditentukan hanya berdasarkan perbedaan kewarganegaraan, dan salah satu pihak adalah Indonesia. Sementara GHR menetapkan perbedaan tersebut tidak hanya karena perbedaan kewarganegaraan. Dengan pengertian tersebut di atas, maka perkawinan campuran antar-agama, bukanlah perkawinan campuran yang diatur dalam UU No.1 tahun 1974.

Perkawinan campuran antar-golongan dan perkawinan campuran antar-tempat tidak termasuk dalam definisi ini. Selain karena tidak ada lagi penggolongan penduduk seperti pada masa penjajahan, UU No.1 tahun 1974 ini berlaku di seluruh wilayah Republik Indonesia terkecuali tanpa memandang suku bangsa.

Menurut Moh. Koesnoe, mengenai perkawinan antara orangorang warga negara Indonesia yang tunduk pada hukum yang berlainan, misalnya yang satu tunduk pada Hukum Adat yang lain tunduk pada Hukum Eropa, pasal 57 tidak berlaku. Demikian pula dengan sendirinya perkawinan antara orang-orang yang berlainan agamanya tidak dapat dimasukkan dalam pengertian ini. Hal ini disebabkan karena dalam pasal 66 UU No.1 tahun 1974 tersebut ditetapkan bahwa orang yang beragama Kristen tidak lagi tunduk kepada ketentuan perundang-undangan yang lama, antara lain $\mathrm{HOCl}^{28}$

Beberapa ahli menyatakan bahwa perkawinan campuran yang diakui dalam UU No. 1 tahun 1974 ini hanyalah perkawinan campuran yang bersifat internasional. Bismar Siregar dalam tulisannya menyatakan bahwa perkawinan campuran antar-agama bukannya tidak diatur dalam UU No.1 tahun 1974. Tetapi dikembalikan kepada Pasal

${ }^{28}$ Moh. Koesnoe, Op. Cit., hal. 131. 
2 UU No.1 tahun 1974, yang menyatakan bahwa perkawinan adalah sah, apabila dilakukan menurut hukum masing-masing agamanya dan kepercayaannya itu. Hal ini berkaitan dengan tujuan perkawinan yang diatur dalam Pasal 1 UU No.1 tahun 1974. ${ }^{29}$

\section{B. Pelaksanaan Perkawinan Campuran}

Berdasarkan Pasal 59 UU No.1 tahun1974 ayat 1 dinyatakan bahwa perkawinan campuran yang dilangsungkan di Indonesia dilakukan menurut UU No.1 tahun 1974. Selanjutnya Pasal 61 UU No.1 tahun 1974 menyatakan bahwa perkawinan campuran dicatat oleh pegawai pencatat yang berwenang. Dalam hal ini pencatatan dilakukan di Kantor Catatan Sipil setempat.

Berdasarkan Pasal 60 UU No.1 tahun 1974, dinyatakan bahwa perkawinan campuran tidak dapat dilangsungkan sebelum terbukti bahwa syarat-syarat perkawinan yang ditentukan oleh hukum yang berlaku bagi masing-masing telah dipenuhi.

Untuk pembuktian bahwa syarat-syarat telah dipenuhi dan tidak adanya rintangan untuk melangsungkan perkawinan campuran maka oleh pihak yang berwenang (menurut hukum yang berlaku bagi mereka), diberikan surat keterangan bahwa syarat-syarat telah dipenuhi. Bagi yang berkewarganegaraan bukan Indonesia, biasanya surat tersebut dikenal sebagai surat keterangan Letter of Ability to Marry yang dikeluarkan oleh kedutaan besar negaranya bagi Indonesia atau perwakilan negaranya di Indonesia.

Perkawinan di luar Indonesia diatur dalam Pasal 56 UU No.1 tahun 1974, perkawinan yang dilangsungkan antara 2 (dua) orang warga negara Indonesia atau seorang Indonesia dengan warga negara asing adalah sah bila dilakukan menurut hukum yang berlaku di negara di mana perkawinan tersebut dilangsungkan. Hal ini dengan pembatasan bahwa bagi warganegara Indonesia, perkawinan tersebut tidak melanggar ketentuan UU No.1 tahun 1974.

Selanjutnya diatur bahwa 1 (satu) tahun setelah suami istri itu kembali di wilayah Indonesia, surat bukti perkawinan itu harus didaftarkan di Kantor Pencatatan Perkawinan tempat tinggal mereka.

Dengan ketentuan tersebut maka dapat dilihat bahwa perkawinan campuran ini dapat dilaksanakan di luar negeri. Dan sah dengan

29 Bismar Siregar, Kawin Campur Antar Agama, Bagaimana Penyelesaiannya, Varia Peradilan, No.75, hal. 147. 
pelaksanaan yang berdasarkan pada hukum setempat, atau dikenal dengan asas lex loci celebrationis.

\section{Perkawinan Antar-Agama Setelah Kemerdekaan Dan UU No.1 Tahun 1974}

Setelah kemerdekaan bangsa Indonesia sebelum dan sesudah berlakunya UU No.1 tahun 1974, dapat dilihat perkembangan yang terjadi khususnya dalam perkawinan campuran antar-agama.

Mengingat pendapat Bapak Bismar Siregar di atas, bagi perkawinan campuran antar-agama beliau mengembalikan kepada iman dan kepercayaan yang dianut oleh para mempelai. Dalam tulisannya beliau menghimbau agar kedua mempelai satu iman, dan

karenanya salah satu pihak harus memilih. ${ }^{30}$

\section{A. Setelah Kemerdekaan, sebelum UU No.1 tahun 1974 (tahun 1952)}

Pada perkara R.A. Soemarni Soeriaatmadja, seorang wanita yang beragama Islam, dan Ursinus Elias Medellu, ${ }^{31}$ seorang lelaki yang tidak beragama Islam, telah ditempuh jalan untuk mengikuti Pasal 8 GHR. Pihak istri, dalam hal ini R.A. Soemarni Soeriaatmadja, memohon penetapan Pengadilan Negeri, untuk menggantikan surat keterangan bahwa bagi pihak istri mengenai keterangan tidak ada keberatan terhadap dilangsungkannya perkawinan itu.

Oleh Pengadilan Negeri telah ditetapkan bahwa menurut Pasal 7 GHR ayat 2, perbedaan agama tidak dapat menghalangi dilangsungkannya perkawinan. Oleh karena itu penolakan untuk melangsungkan perkawinan dari Kepala Kantor Urusan Agama Kecamatan Petamburan dianggap tidak beralasan.

Persoalan ini tiba di Mahkamah Agung, karena ayah dari R.A. Soemarni Soeriaatmadja, selaku wali mujbir dari anak gadisnya dan karenanya termasuk golongan yang merasakan langsung akibat dari penetapan itu, mengajukan kasasi. Dalam permohonan kasasinya ia menyatakan bahwa selaku wali mujbir dari pihak perempuan, ia tidak

\footnotetext{
${ }^{30}$ Bismar Siregar, Ibid.
}

${ }^{31}$ Ketetapan Pengadilan Negeri Jakarta No.432/1952/G dengan Hakim alm. Prof. Mr. Lie Oen Hoek tanggal 17 Juni 1952. 
diundang dan diperiksa keterangannya. Maka permohonan kasasinya dapat diterima oleh Makamah Agung.

Dalam pertimbangannya Mahkamah Agung menyatakan hal-hal yang menarik untuk disimak, sebagai berikut:

1. ...bahwa dalam suatu kenyataan yang tidak dapat sedikit juga kita sangkal bahwa negara kita ini dari dahulu sampai sekarang didiami oleh orang-orang yang berlainan agama dan kultur dan oleh karena itu berlainan hukum perkawinan, perbedaan mana dapat disesuaikan dengan Konstitusi Negara, yang mengakui kebebasan memeluk agama yang disukai.

2. ... adalah sepantasnya bila untuk keselamatan masyarakat sebagai sendi segala hukum diadakan peraturan mengenai hukum yang harus berlaku buat satu masyarakat tentang perkawinan orang-orang yang berlainan agamanya, dengan tidak melebihkan satu agama dari agama yang lain.

3. ...bahwa memang adalah untuk keperluan masyarakat, jika tidak ada larangan hukum terhadap perkawinan antara orang-orang yang berlainan agama itu, karena larangan sedemikian akan memperbanyak anak-anak yang tidak mempunyai orang tua yang sah menurut hukum, yang karena itu selain dari tidak terjamin haknya atas pemeliharaan dan warisan, terutama selama hidupnya mungkin sekali akan menderita penghinaan dalam pergaulannya sebagai anak gampang. ...

4. $\quad$... dalam Ordonansi Perkawinan Campuran sendiri tidak terdapat peraturan yang melebihkan satu agama terhadap agama lain, karena dalam Pasal 6 ayat 1 dengan tegas disebutkan bahwa perkawinan campuran dilakukan menurut hukum yang berlaku bagi pihak laki-laki, yang berarti bila perbuatan itu dipengaruhi hukum agama, menurut keadaannya masing-masing ada pada satu waktu satu hukum agama tertentu yang dilakukan dan pada waktu lain hukum agama lain.

5. Menimbang, bahwa hukum Islam menentang dimungkinkannya oleh ordonansi Perkawinan Campuran itu, perkawinan sah antara seorang perempuan Isalm dengan seorang laki-laki yang bukan Islam, tetapi tidak boleh dilupakan bahwa tiap-tiap hukum yang berlaku di dunia ini dimaksudkan untuk pergaulan hidup bersama, jadi adalah gejala sosiologis dan bukan untuk keselamatan di 
akhirat yang terutama jadi pokok pangkal perhatian bagi tiap-tiap agama.

6. bahwa memang perbedaan hukum positif dengan hukum agama tidak saja ada, jika hukum positif itu merupakan Undang-udang Negara, tetapi di Minangkabau, misalnya yang penduduknya hampir semua memeluk agama Islamn hukum warisnya sangat bertentangan dengan hukum Islam, pertentangan mana dipandang dari sudut hukum Islam tidak dapat dikaburkan dengan pepatah Minangkabau: adat basardi syara, sjaru basandi adat.

Menurut Mahkamah Agung, pasal tersebut tidak ada pengutamaan suatu agama tertentu. Semua hukum yang berdasarkan agama ini dianggap sama rata dihadapan Pasal 6 ayat 1 GHR ini, sehingga merupakan asas persamarataan stelsel hukum.

Selanjutnya dinyatakan bahwa ketetapan dari Pengadilan Negeri yang bersangkutan merupakan pengganti izin yang menurut hukum berlaku untuk R.A. Soemarni Soeriaatmadja, dan hal ini juga dikarenakan atau sehubungan dengan Pasal 7 ayat 2 GHR, yang menyatakan bahwa tidak boleh dilakukan penolakan atas dasar perbedaan agama, nasionalitas atau keturunan.

Dengan pertimbangan-pertimbangan di atas maka Mahkamah Agung menolak permohonan kasasi dari dari ayah calon istri. Dan menurut Mahkamah Agung juga, telah sepantasnya Hakim Pengadilan Negeri tidak menguatkan penolakan Kantor Urusan Agama Kecamatan Petamburan.

\section{B. Setelah Kemerdekaan, sebelum UU No.1 tahun 1974 (tahun 1989)}

Pendirian Mahkamah Agung tentang perkawinan campuran antaragama setelah Kemerdekaan Indonesia dan berlakunya UU No. 1 tahun 1974 dapat dilihat pada perkara Andy Vonny Gani P. dan Adrianus Petrus Hendrik Nelwan ${ }^{32}$.

Kasus ini terjadi dimulai dengan permohonan yang diajukan Andi Vony Gani P., seorang perempuan Islam kepada Pengadilan Negeri

${ }^{32}$ Perkara Andi Vonny Gani P. dan Adrianus Petrus Hendrik Nelwan, Penetapan PN Jakarta Pusat No.382/Pdt/1986/P.N.Jkt.Pst dan MA Reg. No.1400K/Pdt/1986 tanggal 20 Januari 1989. 
Jakarta Pusat untuk diijinkan menikah dengan Adrianus Peter Hendrik Nelwan, seorang pria beragama Kristen Protestan. Permohonan ini diajukan setelah permohonan perkawinan ditolak oleh Kantor Urusan Agama Kecamatan Tanah Abang Jakarta sebagaimana ternyata dalam Surat KUA tanggal 5 Maret 1986 No.KII/NY-I/834/III/1986, dengan alasan bahwa calon suami beragama Kristen Protestan. Permohonan perkawinan ini kemudian ditolak pula oleh Kantor Catatan Sipil Jakarta sebagaimana ternyata dalam surat tanggal 5 Maret 1986 No.665/1.1755.4/C/S/1986, dengan alasan bahwa calon istri beragama Islam. Pengadilan Negeri Jakarta Pusat dalam putusannya tanggal 11 April 1986 ternyata telah menolak permohonan tersebut dan kemudian menyatakan bahwa penolakan untuk melangsungkan perkawinan yang diberikan oleh Kantor Urusan Agama Kecamatan Tanah Abang Jakarta dan Kantor Catatan Sipil Jakarta masng-masing adalah beralasan. Tetapi penolakan Pengadilan negeri Jakarta Pusat atas permohonan Andi Vony Gani P. didasarkan pada pertimbangan bahwa UU No.1 tahun 1974 tidak mengatur perkawinan dari orang-orang yang berbeda agama.

Yang diatur dan dicatat adalah perkawinan dimana calon mempelainya memeluk agama yang sama. Yang beragama Islam dicatat pada Kantor Urusan Agama, sedangkan yang beragama Kristen dicatat pada Kantor Catatan Sipil. Karena perkawinan campuran berbeda agama tidak diatur, maka terdapat suatu penghalang untuk dilangsungkannya perkawinan campuran antar-agama. Pengadilan Jakarta Pusat mendasarkan diri pada Pasal 2 UU No.1 tahun 1974. Jadi faktor agama dimasukkan dalam peraturan hukum. Hukum agama dianggap menjiwai UU No.1 tahun 1974.

Putusan Pengadilan Negeri Jakarta Pusat ini dibatalkan oleh Mahkaman Agung. Alasan yang dipakai terutama adalah yang juga menjadi pegangan sesuai dengan putusan dalam perkara R.A. Soemarni vs. Elias Medellu.

Dalam pertimbangannya, Mahkamah Agung berpendapat bahwa UU No.1 tahun 1974 tidak memuat ketentuan apapun yang menyebutkan bahwa perbedaan agama antara calon suami istri adalah dilarang atau merupakan halangan perkawinan. Sejalan dengan jiwa dari Pasal 27 UUD 1945 yang menyatakan bahwa semua warganegara bersamaan kedudukannya dalam hukum, tercakup didalamnya kesamaan hak asasi untuk kawin dengan sesama warga negara sekalipun berlainan agama. Dan selama oleh undang-undang tidak ditentukan bahwa perbedaan agama merupakan larangan untuk perkawinan, maka asas itu adalah sejalan dengan Pasal 29 UUD 1945 
tentang dijaminnya oleh negara kemerdekaan bagi setiap warga negara untuk memeluk agama masing-masing.

Kemudian dijelaskan oleh Mahkamah Agung bahwa UU No.1 tahun 1974 tidak mengatur tentang perkawinan dimana calon suami istrinya memeluk agama yang berbeda dan sebelum berlakunya UU No.1 tahun 1974, GHR adalah peraturan yang mengatur masalah hubungan hukum ini. Namun menurut Mahkamah Agung, GHR tidak dapat diberlakukan dalam kasus ini, walaupun berdasarkan Pasal 66 UU No.1 tahun 1974 tentang ketentuan peralihan.

Menurut Mahkamah Agung, GHR tidak dapat diberlakukan dalam kasus ini karena terdapat perbedaan prinsip maupun falasafah yang amat lebar antara UU No.1 tahun 1974 dan GHR maupun HOCI, yaitu UU No.1 tahun 1974 menganut asas bahwa perkawinan adalah sah apabila dilakukan menurut hukum masing-masing agamanya dan kepercayaannya. Hal ini merupakan pencerminan atau salah satu perwujudan dari Pancasila sebagai falsafah negara. Perkawinan tidak lagi dilihat hanya dalam hubungan perdata, sebag perkawinan mempunyai hubungan yang erat sekali dengan agama atau kerohanian, sehingga tidak ada perkawinan di luar hukum masing-masing agamanya dan kepercayaannya. Sedangkan perkawinan yang diatur baik oleh Kitab Undang-undang Hukum Perdata (BW), HOCI dan GHR kesemuanya memandang soal perkawinan hanya dalam hubungan perdata saja.

Berdasarkan pertimbangan hukum tersebut selanjutnya Mahkamah Agung berpendapat bahwa telah terjadi kekosongan hukum bagi perkawinan campuran antar-agama Dengan pertimbangan bahwa asas perbedaan agama dari calon suami-istri tidak merupakan larangan perkawinan, maka Mahkamah Agung menyatakan tidaklah dapat dibenarkan kalau karena kekosongan hukum maka kenyataan dan kebutuhan sosial seperti tersebut di atas tidak terpecahkan secara hukum, karena membiarkan masalah tersebut pasti akan menimbulkan dampak negatif di segi kehidupan bermasyarakat maupun beragama yang berupa penyelundupan-penyelundupan nilai-nilai social maupun agama dan atau hukum positif. Untuk itu Mahkamah Agung berpendapat haruslah dapat ditemukan dan ditentukan hukumnya.

Dengan menimbang bahwa Kantor Catatan Sipil adalah satusatunya instansi dalam suatu perkawinan yang kedua calon mempelainya tidak beragama Islam, maka Kantor Catatan Sipil wajib menerima permohonan permohon. Dalam hal ini, tindakan Andi Vony Gani P. yang melakukan permohonan perkawinan kepada Kepala Catatan Sipil dianggap telah atau ditafsirkan bahwa ia telah tidak lagi 
menghiraukan status agamanya, sehingga Pasal 8 sub f UU No.1 tahun 1974 tidak lagi merupakan halangn bagi perkawinan yang mereka kehendaki. Oleh karena itu, Kantor Catatan Sipil ditegaskan wajib menerima permohonan pemohon.

Dasar pikiran ini juga dilandasi pada kenyataan bahwa banyak terjadi perkawinan campuran antar-agama, sehingga sebaiknya perkawinan semacam ini diperbolehkan daripada "... menimbulkan dampak-dampak negatif dan penyelundupan hukum." Kata-kata ini sejalan dengan pertimbangan Mahkamah Agung sebelumnya dalam kasus R.A. Soemarni vs. Elias Medellu.

Mengenai pasal 2 UU No.1 tahun 1974, Sudargo Gautama mendukung pendapat Mahkamah Agung dengan menyatakan pendapatnya bahwa, ${ }^{33}$

... kata-kata yang dipergunakan tidak menutup kemungkinan bagi perkawinan cara lain daripada hanya menurut agama. Karena tidak dikatakah "bahwa perkawinan hanya sah" apabila dilakukan menurut hukum masing-masing agamanya dan kepercayaannya. Tapi yang dikatakan adalah "perkawinan adalah sah", apabila dilakukan menurut hukum masing-masing agamanya dan kepercayaannya itu. Oleh karena itu perkawinan juga sah jika dilangsungkan sesuai dengan ketentuan perkawinan negara.

Lebih lanjut beliau mengatakan, dalam negara modern, sebaiknya lembaga perkawinan dipisahkan dari paham-paham keagamaan, sesuai dengan pemisahan antara kerk en staat. ${ }^{34}$

Dikaitkan dengan masa saat ini dimana telah diberlakukan Undang-undang No.23 tahun 2008 tentang Administrasi Kependudukan yang mulai berlaku tanggal 29 Desember 2006, sepertinya perkawinan antar-agama mendapatkan jawabannya. Berdasarkan Pasal 34 ayat 1 dan 35 berikut penjelasan dari UndangUndang ini, ${ }^{35}$ perkawinan antar agama sebagai salah satu contoh hal. 285 .

${ }^{33}$ Sudargo Gautama, "Segi-segi Hukum Peraturan Perkawinan Campuran", Op. Cit.,

${ }^{34}$ Ibid.

35 Pasal 34 ayat 1 berbunyi "Perkawinan yang sah berdasarkan ketentuan Peraturan Perundang-undangan wajib dilaporkan oleh Penduduk kepada Instansi Pelaksana 
perkawinan yang ditetapkan oleh pengadilan, wajib dicatatkan pada Kantor Catatan Sipil. Dengan adanya aturan ini, sepertinya pertanyaan mengenai pencatatan perkawinan antar-agama telah mendapatkan jawabannya, walaupun masih diperlukan pengamatan lebih lanjut.

\section{Kesimpulan}

Berdasarkan uraian tersebut di atas, maka dapat ditarik kesimpulan bahwa peda perkembangannya perkawinan campuran di Indonesia telah mengalami perubahan. Perkawinan campuran yang berdasarkan GHR lebih luas ruang lingkupnya daripada perkawinan campuran menurut UU No.1 tahun 1974. Perkawinan campuran dalam GHR tidak hanya mencakup perkawinan campuran antar-warga negara, namun juga perkawinan campuran antar-regio (antar-regionaal), Perkawinan campuran antar-tempat (inter-locaal), Perkawinan campuran antar-golongan dan Perkawinan campuran antar-agama. Perkawinan campuran dalam UU No.1 tahun 1974 hanya mencakup perkawinan campur antar warga-negara.

Terdapat perbedaan prinsip maupun falsafah yang amat lebar antara UU No.1 tahun 1974 dan GHR maupun HOCL. Perbedaan tersebut yaitu UU No.1 tahun 1974 menganut asas bahwa perkawinan adalah sah apabila dilakukan menurut hukum masing-masing agamanya dan kepercayaannya. Hal ini merupakan pencerminan atau salah satu perwujudan dari Pancasila sebagai falsafah negara. Perkawinan tidak lagi dilihat hanya dalam hubungan perdata, sebagai perkawinan mempunyai hubungan yang erat sekali dengan agama atau kerohanian, sehingga tidak ada perkawinan di luar hukum masing-masing agamanya dan kepercayaannya. Sedangkan perkawinan yang diatur baik oleh Kitab Undang-undang Hukum Perdata (BW), $\mathrm{HOCI}$ dan GHR kesemuanya memandang soal perkawinan hanya dalam hubungan perdata saja.

Dalam UU No.1 tahun 1974, tidak diatur mengenai perkawinan campuran antar-agama. Dan untuk itu menurut pendapat Mahkamah Agung,

\footnotetext{
di tempat terjadinya perkawinan paling lambat 60 (enampuluh) hari sejak tanggal perkawinan."

Pasal 35 berbunyi "Pencatatan perkawinan sebagaimana dimaksuddalam Pasal 34 berlaku pula bagi:

a. Perkawinan yang ditetapkan oleh Pengadilan; dan

b. Perkawinan Warga negara Asing yang dilakukan di Indonesia atas permintaan

Warga Negara Asing yang bersangkutan.

Penjelasan Pasal 35 berbunyi Huruf a Yang dimaksud dengan "Perkawinan yang ditetapkan oleh Pengadilan adalah perkawinan yang dilakukan antar-umat yang berbeda agama".
} 
di Indonesia mengalami kekosongan hukum. Namun untuk mencegah dampak negatif, penyelundupan hukum dan karena sifat masyarakat Indonesia yang heterogen dan pluralistik, maka Mahkamah Agung menunjuk Kantor Catatan Sipil untuk melaksanakan perkawinan campuran antaragama. Namun untuk saat ini telah ada ketentuan yang memastikan bahwa perkawinan campuran antar-agama yang telah mendapatkan penetapan pengadilan dapat dicatatkan di Kantor Catatan Sipil. 


\section{Daftar Pustaka}

Gautama, Sudargo. Hukum Perdata Internasional Indonesia, Jilid III Bagian 1, Bandung; Alumni, 1981. Binacipta, 1987.

. Pengantar Hukum Perdata Internasional Indonesia, Jakarta:

. Hukum Antargolongan Suatu Pengantar, Jakarta: Ichtiar Baru Van Hoeve, Cet. 11, 1993.

. Segi-segi Hukum Peraturan Perkawinan Campuran, Bandung: Citra Aditya Bakti, 1996. Warga Negara dan orang Asing, Bandung: Alumni, 1997.

Ichtianto. Disertasi: Perkawinan Campuran di Indonesia, Jakarta.

Kartohadiprodjo, Soediman, Pengantar Tata Hukum di Indonesia, Jakarta: Pembangunan Ghalia Indonesia, 1984.

Koesnoe, Moh. Istilah Perkawinan Campuran Sebagai Suatu Pengertian Hukum di Indonesia, Varia Peradilan No.159.

Saleh, K. Wantjik. Hukum Perkawinan Indonesia, Jakarta: Ghalia Indonesia, 1976.

Siregar, Bismar. "Kawin Campur Antar Agama, Bagaimana Penyelesaiannya", Varia Peradilan, No.75.

Sugiastuti, Natasya Yunita. Tradisi Hukum Cina: Negara dan Masyarakat (Studi mengenai peristiwa-peristiwa Hukum di Pulau Jawa Zaman Kolonial 1870-1942), Jakarta: Program Pasca Sarjana Fakultas Hukum Universitas Indonesia, 2003.

Supomo, R. Sistem Hukum di Indonesia, Jakarta: Pradnya Paramita, 1981.

Supriadi, Wila Chandrawila. Hukum Perkawinan Indonesia \& Belanda, Suatu Penelitian Sejarah Hukum Perbandingan tentang Hukum Perkawinan Indonesia dan Belanda dalam Periode Tahun 1945 Sampai Sekarang, Bandung: Mandar Maju, 2002.

\section{Peraturan Perundang-Undangan}

Reglement op het Beleid der Regering van Nederlands-Indie disingkat Regeringsreglement (RR) atau Peraturan Pemerintah. RR Lama diberlakukan dengan Stb.1855:2 pada tanggal 2 September 1854; 
sedangkan RR baru diberlakukan dengan Stb.1907:204 pada tanggal 31 Desember 1906 yang diubah dengan Stb, 1919:621 dan mulai berlaku tanggal 1 Januari 1920.

Penetapan Raja atau Beslit Kerajaan 29 Desember 1896 No.23, Staatblad No.1898:158 (Regeling op de Gemengde Huwelijken), atau Peraturan Perkawinan Campuran (GHR).

Huwelijk Ordonnantie Christen-Inlanders Java, Minahasa en Amboina, (Ordonansi Perkawinan Indonesia - Kristen untuk Jawa, Minahasa dan Ambon) Staatblad 1933 No.74 (HOCI).

RI., Undang-Undang No.62 tahun 1958 tentang Kewarganegaraan Republik Indonesia, Tambahan Lembaran Negara No.1647. . Undang-Undang No.1 tahun 1974 tentang Perkawinan, Tambahan Lembaran Negara No.3050. . Undang-Undang No.23 tahun 2008 tentang Administrasi Kependudukan,

Penetapan Pengadilan Negeri Jakarta No.432/1952/G tanggal 17 Juni 1952 dan Putusan MA tanggal 16 Pebruari 1955.

Penetapan PN Jakarta Pusat No.382/Pdt/1986/P.N.Jkt.Pst dan MA Reg. No.1400K/Pdt/1986 tanggal 20 Januari 1989. 